\title{
RADIOCARBON AND STABLE CARBON ANALYSIS OF DISSOLVED METHANE AND CARBON DIOXIDE FROM THE PROFILE OF A RAISED PEAT BOG
}

\author{
M H Garnett ${ }^{1,2} \cdot$ S M L Hardie ${ }^{3}$ C Murray ${ }^{1}$ \\ ABSTRACT. We developed and tested a new method to separate $\mathrm{CO}_{2}$ and $\mathrm{CH}_{4}$ from bulk gas samples for radiocarbon and \\ stable-carbon analysis that utilizes a zeolite molecular sieve. To validate the technique, tests were performed using a suite of \\ standard gases, composed of $\mathrm{CO}_{2}$ and $\mathrm{CH}_{4}$ of distinctly different isotopic composition. We employed the method to investi- \\ gate the carbon isotopic composition of samples of dissolved $\mathrm{CO}_{2}$ and $\mathrm{CH}_{4}$ collected in situ from the near surface to deep lay- \\ ers of an ombrotrophic raised peat bog. Results showed that the age of both the $\mathrm{CO}_{2}$ and $\mathrm{CH}_{4}$ components of the dissolved \\ gases increased with depth from $\sim 0-300 \mathrm{BP}$ at $0.25 \mathrm{~m}$ to $\sim 4000 \mathrm{BP}$ at $4 \mathrm{~m} . \mathrm{CH}_{4}$ was mainly similar or slightly older in age \\ compared to $\mathrm{CO}_{2}$, with the greatest difference in ages occurring at $1 \mathrm{~m}$ depth where $\mathrm{CH}_{4}$ was older by $430-615 \mathrm{yr}$. The $\delta^{13} \mathrm{C}$ \\ values of $\mathrm{CO}_{2}$ increased with depth from $-12.4 \%$ and $-8.0 \%$ at $0.25 \mathrm{~m}$ to $+6.9 \%$ and $+8.3 \%$ at $4 \mathrm{~m}$, whereas the $\delta^{13} \mathrm{C}$ of $\mathrm{CH}_{4}$ \\ stayed in the range $-58.4 \%$ to $-70.6 \%$. The ${ }^{14} \mathrm{C}$ results from the deepest layers are consistent with a similar source for both \\ gases. ${ }^{14} \mathrm{C}$ ages for the $\mathrm{CO}_{2}$ component were younger compared to $\mathrm{CH}_{4}$, within the shallower depths of the peat bog $(\leq 1 \mathrm{~m})$ \\ and demonstrate the incorporation of acrotelm-derived respired $\mathrm{CO}_{2}$ into the catotelm.
}

\section{INTRODUCTION}

Peatlands are sources of two of the most important greenhouse gases, carbon dioxide $\left(\mathrm{CO}_{2}\right)$ and methane $\left(\mathrm{CH}_{4}\right)$. Given the vast quantities of carbon stored in global peatlands, understanding the production of these gases is of considerable importance and over recent years much research effort has been directed at understanding the peatland carbon balance by monitoring surface emissions of both $\mathrm{CO}_{2}$ and $\mathrm{CH}_{4}$ (Lansdown et al. 1992; Chapman and Thurlow 1996; Nykänen et al. 2003). Fewer studies have investigated the generation of these gases deep within the peat profile (Steinmann et al. 2008), which is clearly required for a more complete understanding of these systems. Even less has the radiocarbon $\left({ }^{14} \mathrm{C}\right)$ content of deep peat gases been investigated, yet such measurements provide valuable information on the age and source of both $\mathrm{CO}_{2}$ and $\mathrm{CH}_{4}$, and the overall rate at which carbon is cycled.

The most extensive investigation of the carbon isotopic composition of dissolved $\mathrm{CO}_{2}$ and $\mathrm{CH}_{4}$ in deep peats reported so far has been by Clymo and Bryant (2008). They found that the ${ }^{14} \mathrm{C}$ ages of both $\mathrm{CO}_{2}$ and $\mathrm{CH}_{4}$ were broadly similar at most depths throughout the peat profile of a raised mire in Scotland, UK, although $\mathrm{CH}_{4}$ was generally older than $\mathrm{CO}_{2}$ above $4 \mathrm{~m}$ depth, but younger than $\mathrm{CO}_{2}$ below $4 \mathrm{~m}$. Both dissolved gases were considerably younger than the bulk peat and dissolved organic carbon (DOC) extracted from the same depths. Modeling of the results suggested that diffusion was responsible for $99 \%$ of dissolved gas movement at that site.

In North American fens and bogs, Chanton et al. (2008) found that the ${ }^{14} \mathrm{C}$ concentrations of dissolved $\mathrm{CO}_{2}$ and $\mathrm{CH}_{4}$ were so similar that they suggested that analysis of ${ }^{14} \mathrm{CO}_{2}$ alone could suffice as a proxy for ${ }^{14} \mathrm{CH}_{4}$. Chanton et al. (2008) and Chasar et al. (2000) found that both $\mathrm{CO}_{2}$ and $\mathrm{CH}_{4}$ were either similar in age to DOC, or intermediate between the age of DOC and the surrounding bulk peat, in contrast to the results of Clymo and Bryant (2008). These findings highlight important differences between these peatlands, with hydraulic conductivity appearing to be an important factor in controlling the movements of the various peatland carbon pools (Chanton et al. 2008; Clymo and Bryant 2008).

${ }^{1}$ NERC Radiocarbon Facility (Environment), Rankine Avenue, East Kilbride G75 0QF, United Kingdom.

${ }^{2}$ Corresponding author. Email: M.Garnett@nercrcl.gla.ac.uk.

${ }^{3}$ Chemistry Department, Joseph Black Building, University of Glasgow, Glasgow G12 8QQ, United Kingdom; Present address: Scottish Crop Research Institute, Invergowrie, Dundee DD2 5DA, United Kingdom. 
Earlier studies investigating the ${ }^{14} \mathrm{C}$ content of dissolved $\mathrm{CO}_{2}$ and $\mathrm{CH}_{4}$ in peats were reported by Aravena et al. (1993) who found that $\mathrm{CO}_{2}$ and $\mathrm{CH}_{4}$ recovered from the same depth had similar ${ }^{14} \mathrm{C}$ ages, albeit at only the 3 depths from where the gases were analyzed. Furthermore, contrary to results from other studies, the age of dissolved gas samples did not consistently increase with depth as samples extracted from mid-depths were slightly younger than those above. Charman et al. (1999) investigated the ${ }^{14} \mathrm{C}$ composition of dissolved $\mathrm{CO}_{2}$ and $\mathrm{CH}_{4}$ in an oceanic peatland in southwest England, UK. Here, ${ }^{14} \mathrm{C}$ ages of gases were reported from just 2 depths (150-170 and 230-250 $\mathrm{cm}$ ); in both cases the $\mathrm{CH}_{4}$ component was found to be significantly older than the $\mathrm{CO}_{2}$ fraction. In contrast, Charman et al. (1994) had earlier reported ${ }^{14} \mathrm{C}$ ages for dissolved $\mathrm{CO}_{2}$ that were older than those for $\mathrm{CH}_{4}$ from a forested continental peatland in Canada.

$\delta^{13} \mathrm{C}$ values of dissolved peat gases can provide further information on the source of these gases, and have been reported in all of the above studies, in addition to others (e.g. Waldron et al. 1999; Steinmann et al. 2008). Clymo and Bryant (2008) review some of these studies in the context of their own results, showing general agreement that $\delta^{13} \mathrm{C}$ values of dissolved $\mathrm{CO}_{2}$ increase with depth to between $+5 \%$ to $+10 \%$ at depths below several meters. The picture for $\mathrm{CH}_{4}$ is less clear. Clymo and Bryant (2008) found $\delta^{13} \mathrm{C}$ values for $\mathrm{CH}_{4}$ were consistently around -65 to $-60 \%$ below $2 \mathrm{~m}$ depth, but became more ${ }^{13} \mathrm{C}$-depleted towards the peat surface. However, these results differed considerably to those reported by Waldron et al. (1999), where $\delta^{13} \mathrm{C}$ of $\mathrm{CH}_{4}$ ranged between $-80 \%$ and $-70 \%$ with no apparent pattern with depth, despite being collected at the same peatland, just $75 \mathrm{~m}$ away. Hornibrook et al. (1997) presented further conflicting results showing that within the upper $\sim 1 \mathrm{~m}$ of the peatland they studied, $\mathrm{CH}_{4} \delta^{13} \mathrm{C}$ values increased towards the surface. Coleman et al. (1988) provide an extensive collection of carbon isotope results $\left({ }^{14} \mathrm{C}\right.$ and $\left.\delta^{13} \mathrm{C}\right)$ for methane in groundwater from shallow sediments in Illinois, USA, and suggest that at least some of this methane is derived from buried peat deposits.

The above studies represent most of the available published work on the ${ }^{14} \mathrm{C}$ content of dissolved $\mathrm{CO}_{2}$ and $\mathrm{CH}_{4}$ in peats, which is surprising given the global importance of peatlands to the production of these greenhouse gases. Of these few studies reported, most have been lacking in terms of sampling resolution and replication (particularly where ${ }^{14} \mathrm{C}$ measurements are concerned). Moreover, Clymo and Bryant (2008) stress that while the same processes observed in their study must operate within other peatlands, it should not be assumed that their results can be extrapolated to other sites. Thus, to gain a better understanding of greenhouse gas production in the deeper layers of peatlands, further studies from additional sites are clearly required.

Difficulties in both the collection of dissolved $\mathrm{CO}_{2}$ and $\mathrm{CH}_{4}$ samples from the deep layers of a peatland (many of which extend to 8-10 m) and subsequent isotopic analysis may partly explain the limited number of studies. Clymo and Bryant (2008) discuss some of the problems encountered by earlier workers in collecting suitable samples. They comment that, while the methods used by Aravena et al. (1993) and Charman et al. $(1994,1999)$ relatively rapidly collect dissolved peatland gases and pore water, the technique may not be suitable for peats of lower hydraulic conductivity. Furthermore, an additional stage to separate dissolved gases from the pore water was required. Much better would be to collect gas samples in situ and over longer periods of time, thus minimizing disturbance effects. Garnett and Hardie (2009) reported a passive sampling method that allowed for the in situ collection of dissolved $\mathrm{CO}_{2}$ with minimal site disturbance, however, their method is not suitable for the collection of $\mathrm{CH}_{4}$. Although the method employed by Clymo and Bryant (2008) overcame many of the aforementioned difficulties, it required the manufacture of specialized equipment and a somewhat lengthy installation and sampling procedure. Furthermore, once samples were collected and returned to the laboratory, the cryogenic separation of the $\mathrm{CO}_{2}$ and $\mathrm{CH}_{4}$ components was not straightforward. 
We therefore considered that there was a need to develop a new sampling method for the collection of dissolved peat gases that was inexpensive and easy to install and operate, and new laboratory methods that were reliable for the separation of the $\mathrm{CO}_{2}$ and $\mathrm{CH}_{4}$ components for carbon isotope analysis. Development of these methods would help reduce some of the obstacles to the collection of these sample types, allowing investigation of additional sites with greater replication. Here, we describe new methods for both the in situ collection, and subsequent isolation, of dissolved $\mathrm{CO}_{2}$ and $\mathrm{CH}_{4}$ samples from peat in preparation for both ${ }^{14} \mathrm{C}$ and stable carbon analysis. We present results from (i) a thorough test of the laboratory procedures to separate $\mathrm{CO}_{2}$ and $\mathrm{CH}_{4}$ using standard gases of known isotopic composition, and (ii) application of the procedures to collect and analyze samples of dissolved peat gases from an ombrotrophic bog.

\section{METHODS}

\section{Laboratory Methods}

The method developed to isolate the $\mathrm{CO}_{2}$ and $\mathrm{CH}_{4}$ components of bulk gas samples involved 2 stages. The first stage involved removal of the $\mathrm{CO}_{2}$ fraction of the sample gases using a molecular sieve cartridge (MSC) and conversion of the $\mathrm{CH}_{4}$ component to $\mathrm{CO}_{2}$. In the second stage, the $\mathrm{CO}_{2}$ fraction was recovered from the MSC.

Firstly, a glass flask (volume $\sim 215 \mathrm{~mL}$ ) containing the sample gases was attached to a vacuum rig via a MSC. Next, an excess of high-purity oxygen was added to the flask (determined by monitoring pressures with a pressure transducer). The gas mixture in the flask was then passed through the MSC and into a vacuum rig, resulting in the trapping of the $\mathrm{CO}_{2}$ component on the MSC. The MSC used has previously been described and tested several times before for collection of $\mathrm{CO}_{2}$ from various atmospheres (e.g. Hardie et al. 2005; Garnett and Hardie 2009; Garnett and Hartley 2010). Very briefly, it consists of a quartz glass tube containing $\sim 3-4 \mathrm{~g}$ of Type 13X zeolite molecular sieve (1/ 16 " pellets, BDH, UK) held within a central chamber using quartz wool. Prior to use, the MSC was desorbed by heating $\left(500{ }^{\circ} \mathrm{C}\right)$ under vacuum for $1.5 \mathrm{hr}$, cooled, and filled to atmospheric pressure using high-purity nitrogen gas.

After exiting the MSC, the gases that were not adsorbed were passed over platinum-alumina pellets heated to $950{ }^{\circ} \mathrm{C}$, which acted as a catalyst to convert the $\mathrm{CH}_{4}$ component of the sample gas to $\mathrm{CO}_{2}$. This $\mathrm{CH}_{4}$-derived $\mathrm{CO}_{2}$ was then cryogenically purified using a slush trap (mix of dry ice and etha$\left.\mathrm{nol} ;-78^{\circ} \mathrm{C}\right)$ to remove water, and liquid nitrogen $\left(-196{ }^{\circ} \mathrm{C}\right)$ to separate $\mathrm{CO}_{2}$ from other gases. The volume (at standard temperature and pressure) of the resultant $\mathrm{CH}_{4}$-derived $\mathrm{CO}_{2}$ was determined using a calibrated volume connected to a pressure transducer. Subsequently, the $\mathrm{CO}_{2}$ component of the sample gas was recovered from the MSC by heating $\left(500{ }^{\circ} \mathrm{C}\right)$ while attached to a vacuum rig (Hardie et al. 2005), purified, and the volume determined.

Both $\mathrm{CO}_{2}$ and $\mathrm{CH}_{4}$-derived $\mathrm{CO}_{2}$ components of the flask gas were measured for ${ }^{14} \mathrm{C}$ content and $\delta^{13} \mathrm{C} . \delta^{13} \mathrm{C}$ values ${ }^{13} \mathrm{C} /{ }^{12} \mathrm{C}$ ratio in \%o units relative to the standard Vienna Pee Dee belemnite; VPDB) were determined on an aliquot of the recovered samples of $\mathrm{CO}_{2}$ using a dual inlet isotope ratio mass spectrometer (VG Optima, Micromass, UK) at the NERC Radiocarbon Facility. Sample $\mathrm{CO}_{2}$ was also reduced to graphite by $\mathrm{Fe} / \mathrm{Zn}$ reduction (Slota et al. 1987) and analyzed by accelerator mass spectrometry (AMS) for ${ }^{14} \mathrm{C}$ content at the Scottish Universities Environmental Research Centre (SUERC), East Kilbride, UK (Freeman et al. 2007). All ${ }^{14} \mathrm{C}$ results were normalized to a $\delta^{13} \mathrm{C}$ of $-25 \%$ to account for mass-dependent fractionation, and expressed as conventional ${ }^{14} \mathrm{C}$ ages $\left({ }^{14} \mathrm{C} \mathrm{yr}\right.$ BP) and percent modern carbon (pMC; Stuiver and Polach 1977). Following convention, measurement uncertainties associated with isotope concentrations are expressed as standard deviations. 


\section{Test of Laboratory Methods}

We tested the method to separate the $\mathrm{CO}_{2}$ and $\mathrm{CH}_{4}$ components of sample gases by preparing a suite of 6 standard gases composed of mixtures of $\mathrm{CO}_{2}$ and $\mathrm{CH}_{4}$ of known isotopic composition. The $\mathrm{CH}_{4}$ component of the standard gases was derived from tank gas, which we had previously determined to have a ${ }^{14} \mathrm{C}$ concentration of $\sim 0.15 \mathrm{pMC}$ (indicating virtually no ${ }^{14} \mathrm{C}$ ) and a $\delta^{13} \mathrm{C}$ value of approximately $-39.5 \%$. In contrast, the $\mathrm{CO}_{2}$ component was highly ${ }^{14} \mathrm{C}$-enriched $(116.35 \mathrm{pMC})$ and had a $\delta^{13} \mathrm{C}$ value of $-27 \%$, being derived from barley mash that had been formerly used in international radiocarbon intercomparison exercises (Gulliksen and Scott 1995). Standard gases were prepared with volumes of $\mathrm{CO}_{2}$ that ranged between 4.6 and $25.1 \mathrm{~mL}$, and between $\sim 5$ and $\sim 10 \mathrm{~mL}$ for $\mathrm{CH}_{4}$; because $\mathrm{CH}_{4}$ does not completely condense at liquid nitrogen temperatures (Clymo and Bryant 2008), we were unable to make accurate measurements of the $\mathrm{CH}_{4}$ component of the standard gas mixtures in a calibrated volume prior to processing. ${ }^{14} \mathrm{C}$ analysis was performed on the $\mathrm{CO}_{2}$ and $\mathrm{CH}_{4}$ recovered from 4 of the 6 standard gases.

\section{Field Experiment}

We collected samples of dissolved gas from a raised peat bog using evacuated glass flasks (volume $\sim 215 \mathrm{~mL}$ ) connected to stainless steel sampling probes previously described and tested by Garnett and Hardie (2009). Briefly, the probes were composed of lengths of steel tubing (6 mm OD) carefully pushed into the surface of the peat to the depth under investigation. The gas sampling end of the probes was sealed except for 6 holes $(2 \mathrm{~mm}$ diameter) that had been drilled through the stainless steel tube. The holes were covered by a $5 \mathrm{~cm}$ length of gas permeable hydrophobic filter (Accurel PP V8/2 HF, Membrana GmbH, Germany; Gut et al. 1998), thus allowing gas exchange between the peat and the inside of the sampling tube, but preventing entry of liquid water. Joins were covered with heat shrink and rubber sealant (Plasti-dip, Minnesota, USA) to ensure they were leak-tight. The opposite end of the sampling probes protruded slightly above the peat surface where a gas-tight coupling (Colder Products Company, USA) was used to connect an evacuated flask via a short $(5 \mathrm{~cm})$ length of Tygon tubing. When not being used for sampling, a plastic clip (WeLoc ${ }^{\circledR}$, Scandinavia Direct, UK) was placed over the Tygon tubing to form an additional seal.

The field samples were collected from Langlands Moss, an ombrotrophic raised mire near East Kilbride, Scotland, UK $\left(55^{\circ} 44^{\prime} 05.9^{\prime \prime} \mathrm{N}, 4^{\circ} 10^{\prime} 26.1^{\prime \prime} \mathrm{W}\right)$. The sampling probes were inserted to 4 depths $(0.25,1,2$, and $4 \mathrm{~m}$ ) at 2 locations (Sites A and B) situated $20 \mathrm{~m}$ apart on 13 November 2009. These sampling locations were approximately $3 \mathrm{~m}$ away from sites previously used by Garnett and Hardie (2009) to collect dissolved $\mathrm{CO}_{2}$. After insertion into the peat profile, each probe was briefly evacuated using a battery-powered air pump (MiDan Co., Chino, California, USA) in order to reduce the small amount of atmospheric $\mathrm{CO}_{2}$ that would have been present. Next, the probes were allowed to regain atmospheric pressure with $\mathrm{CO}_{2}$-free air by opening them to atmosphere via a cartridge containing soda lime (BDH, UK). The probes were left in situ for several weeks until, on 3

December 2009, evacuated flasks were attached to each probe. The clips sealing the surface end of each probe were removed and the valves on each of the evacuated flasks slowly opened, facilitating gas transfer from probe to flask. Flasks were recovered after 7 (Site A) and 12 (Site B) days of sampling, returned to the laboratory, and stored in the dark until required for processing.

\section{RESULTS}

\section{Test of Laboratory Methods}

From each of the 6 standard gases of prepared mixtures of $\mathrm{CO}_{2}$ and $\mathrm{CH}_{4}$, we recovered $100 \%$ of the $\mathrm{CO}_{2}$ fraction from the MSCs (Table 1). The volume of $\mathrm{CH}_{4}$ in the standard gas mixtures was not 
accurately determined prior to processing; however, the recovered volumes of $\mathrm{CH}_{4}$-derived $\mathrm{CO}_{2}$ were very similar to the expected volume of $\mathrm{CH}_{4}$ within the bulk standard gases determined from earlier tests. For the $\mathrm{CO}_{2}$ component of recovered standard gases, all ${ }^{14} \mathrm{C}$ results were within analytical uncertainty $(<2 \sigma)$ of the international consensus value (Table 1; $116.35 \mathrm{pMC}$; Gulliksen and Scott 1995). In addition, $\delta^{13} \mathrm{C}$ values were all within analytical uncertainty $(<2 \sigma)$ of the original value $(-27.0 \%)$, with the exception of 1 sample that was slightly ${ }^{13} \mathrm{C}$-depleted.

Table 1 Results of the laboratory test of $\mathrm{CO}_{2}$ and $\mathrm{CH}_{4}$ separation for carbon isotope measurement. Standard gases composed of various mixtures of $\mathrm{CO}_{2}$ and $\mathrm{CH}_{4}$ were prepared. Individual gases were then separated and analyzed for volume, ${ }^{14} \mathrm{C} \mathrm{pMC}$ and $\delta^{13} \mathrm{C}$ (see text for details). All volumes \pm 0.1 $\mathrm{mL}$, except those noted by a volumes approximate. ${ }^{\mathrm{b}} \mathrm{CH}_{4}$ results not corrected for ${ }^{14} \mathrm{C}$ background (therefore used to quantify the ${ }^{14} \mathrm{C}$ introduced during sample processing).

\begin{tabular}{|c|c|c|c|c|c|c|c|c|c|}
\hline \multicolumn{2}{|c|}{$\begin{array}{l}\text { Composition of } \\
\text { standard gas }\end{array}$} & \multicolumn{4}{|c|}{ Recovered $\mathrm{CO}_{2}$ fraction } & \multicolumn{4}{|c|}{$\mathrm{CH}_{4}$ fraction (recovered as $\mathrm{CO}_{2}$ ) } \\
\hline $\begin{array}{l}\mathrm{CO}_{2} \\
(\mathrm{~mL})\end{array}$ & $\begin{array}{l}\mathrm{CH}_{4} \\
(\mathrm{~mL})^{\mathrm{a}}\end{array}$ & \begin{tabular}{|l}
$\begin{array}{l}\text { Volume } \\
(\mathrm{mL})\end{array}$ \\
[yield $(\%)]$
\end{tabular} & $\begin{array}{l}\text { Publication } \\
\text { code } \\
\text { (SUERC-) }\end{array}$ & $\begin{array}{l}{ }^{14} \mathrm{C} \mathrm{pMC} \\
\pm 1 \sigma\end{array}$ & $\begin{array}{l}\delta^{13} \mathrm{C}_{\mathrm{VPDB}} \\
\pm 0.1 \% \text { o }\end{array}$ & $\begin{array}{l}\text { Vol- } \\
\text { ume } \\
(\mathrm{mL})\end{array}$ & $\begin{array}{l}\text { Publication } \\
\text { code } \\
\text { (SUERC-) }\end{array}$ & $\begin{array}{l}{ }^{14} \mathrm{C} \mathrm{pMC}^{\mathrm{b}} \\
\pm 1 \sigma\end{array}$ & $\begin{array}{l}\delta^{13} \mathrm{C}_{\mathrm{VPDB}} \\
\pm 0.1 \% \text { o }\end{array}$ \\
\hline 0 & $\sim 5$ & $\mathrm{n} / \mathrm{a}$ & $\mathrm{n} / \mathrm{a}$ & $\mathrm{n} / \mathrm{a}$ & $\mathrm{n} / \mathrm{a}$ & 4.6 & 26828 & $0.17 \pm 0.01$ & -39.7 \\
\hline 5.7 & $\sim 5$ & $5.7[100]$ & $\mathrm{n} / \mathrm{a}$ & $\mathrm{n} / \mathrm{a}$ & -27.2 & 4.5 & $\mathrm{n} / \mathrm{a}$ & $\mathrm{n} / \mathrm{a}$ & -39.6 \\
\hline 9.7 & $\sim 5$ & $9.7[100]$ & $\mathrm{n} / \mathrm{a}$ & $\mathrm{n} / \mathrm{a}$ & -26.8 & 4.5 & $\mathrm{n} / \mathrm{a}$ & $\mathrm{n} / \mathrm{a}$ & -39.7 \\
\hline 4.6 & $\sim 5$ & $4.6[100]$ & 26837 & $116.65 \pm 0.51$ & -27.2 & 5.8 & 26829 & $0.14 \pm 0.01$ & -39.5 \\
\hline 25.1 & $\sim 5$ & $25.1[100]$ & 26834 & $116.68 \pm 0.54$ & -27.1 & 4.9 & 26827 & $0.64 \pm 0.01$ & -39.6 \\
\hline 9.8 & $\sim 10$ & $9.8[100]$ & 26832 & $116.76 \pm 0.56$ & -27.5 & 8.1 & 26830 & $0.14 \pm 0.01$ & -39.8 \\
\hline 21.3 & $\sim 10$ & $21.3[100]$ & 26833 & $117.10 \pm 0.51$ & -27.1 & 10.2 & 26831 & $0.15 \pm 0.01$ & -39.7 \\
\hline
\end{tabular}

The ${ }^{14} \mathrm{C}$ content of a sample of $\mathrm{CH}_{4}$ without added $\mathrm{CO}_{2}\left(\mathrm{CH}_{4}\right.$ blank $)$ was determined to quantify the ${ }^{14} \mathrm{C}$ background of the laboratory methods, for which we obtained a value of $0.17 \pm 0.01 \mathrm{pMC}$ (Table 1). For the mixed standard gases, the $\mathrm{CH}_{4}$ component in 3 of the 4 samples was within measurement uncertainty $(<2 \sigma)$ of the $\mathrm{CH}_{4}$ background sample, indicating insignificant contamination from the ${ }^{14} \mathrm{C}$-enriched $\mathrm{CO}_{2}$ component. However, the ${ }^{14} \mathrm{C}$ content of $\mathrm{CH}_{4}$ from the standard gas with the largest volume of $\mathrm{CO}_{2}(25 \mathrm{~mL})$, was slightly ${ }^{14} \mathrm{C}$-enriched compared to the other samples, suggesting a small amount of contamination. The $\delta^{13} \mathrm{C}$ value of all $\mathrm{CH}_{4}$ samples ranged from -39.5 to $-39.8 \%$, and, therefore, all overlapped with each other at $<2 \sigma$ analytical uncertainty.

\section{Field Experiment}

Between 2.0 and $10.7 \mathrm{~mL}$ of $\mathrm{CO}_{2}$ were recovered from the field-collected samples, and there was no clear pattern between the volume of $\mathrm{CO}_{2}$ recovered and depth (Table 2). However, the volume of $\mathrm{CH}_{4}$ collected appeared to increase with depth, ranging from $1.5 \mathrm{~mL}$ at $0.25 \mathrm{~m}$, to a maximum of $19.9 \mathrm{~mL}$ and $18.2 \mathrm{~mL}$ at $2 \mathrm{~m}$ and $4 \mathrm{~m}$, respectively (Site B). There were clear trends with depth in the ${ }^{14} \mathrm{C}$ age of both the $\mathrm{CO}_{2}$ and $\mathrm{CH}_{4}$ components of field samples (Figure 1a). $\mathrm{CO}_{2}$ ranged in age from $149 \pm 37$ and $0 \pm 37 \mathrm{BP}$ for samples collected at $0.25 \mathrm{~m}$ depth, to $4019 \pm 64$ and $3874 \pm 62 \mathrm{BP}$ at $4 \mathrm{~m}$ depth. The ${ }^{14} \mathrm{C}$ age of the $\mathrm{CH}_{4}$ component followed a very similar pattern, although tended to be older than $\mathrm{CO}_{2}$ collected from the same depth. This difference between the ${ }^{14} \mathrm{C}$ age of the $\mathrm{CO}_{2}$ and $\mathrm{CH}_{4}$ components was greatest at $1 \mathrm{~m}$ depth; the age difference between the 4-m samples was much less and insignificant when measurement uncertainty was taken into consideration.

Conversely, $\delta^{13} \mathrm{C}$ values for $\mathrm{CO}_{2}$ and $\mathrm{CH}_{4}$ components differed considerably (Table 2). The $\mathrm{CO}_{2}$ component of samples became significantly ${ }^{13} \mathrm{C}$-enriched with depth, ranging from $-12.4 \%$ and $-8.0 \%$ in samples from $0.25 \mathrm{~m}$, to $+6.9 \%$ and $+8.3 \%$ at $4 \mathrm{~m}$ (Figure $1 \mathrm{~b}$ ). However, $\mathrm{CH}_{4}$ was always con- 

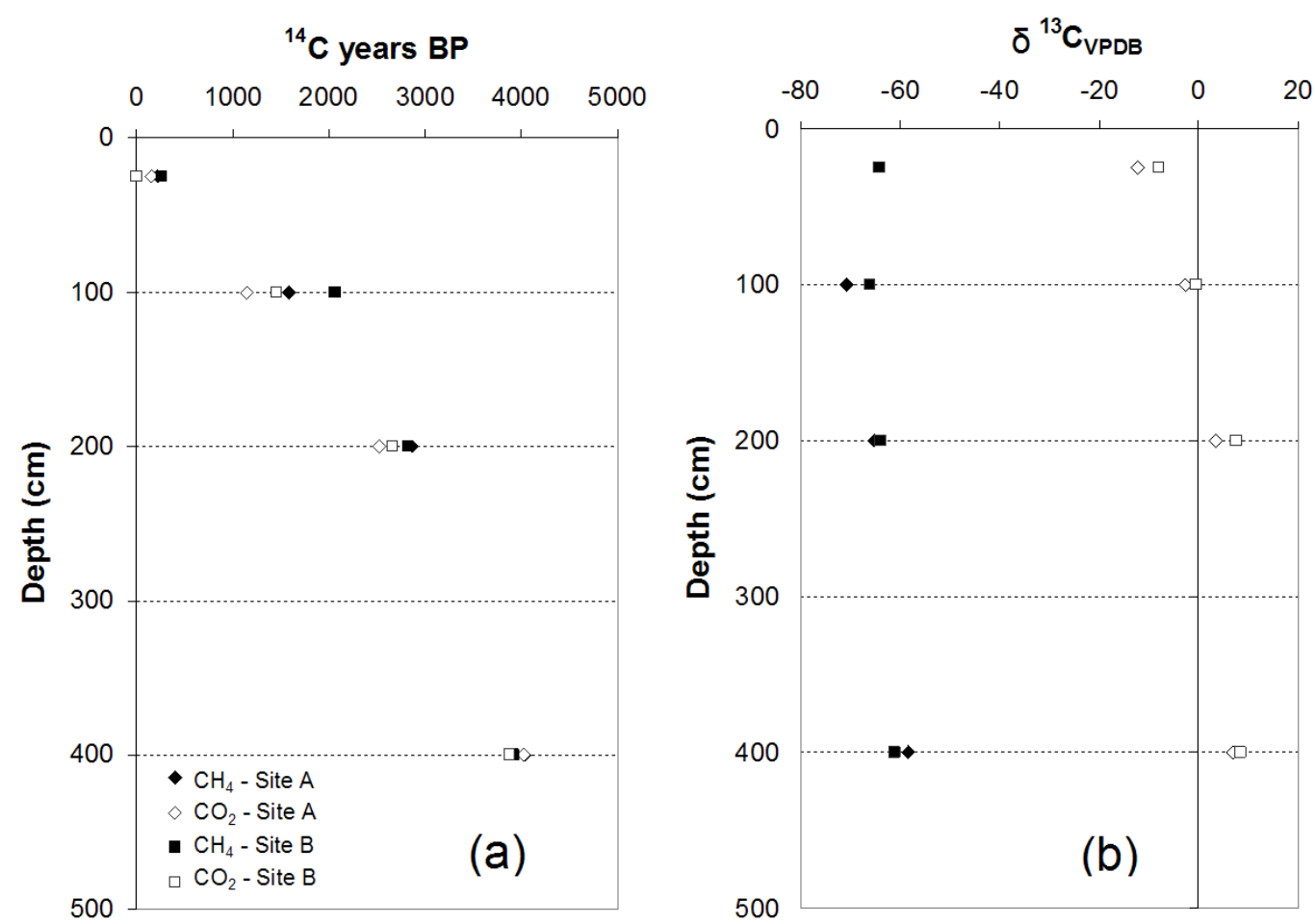

Figure 1 (a) Radiocarbon age $\left({ }^{14} \mathrm{C}\right.$ yr BP) and (b) $\delta{ }^{13} \mathrm{C}_{\mathrm{VPDB}}\left(\%\right.$ ) of dissolved $\mathrm{CO}_{2}$ and $\mathrm{CH}_{4}$ collected from different depths at Langlands Moss, near East Kilbride, UK.

Table 2 Field study results. Dissolved peat gases were collected from various depths of Langlands Moss raised peat bog using evacuated flasks attached to sampling probes. $\mathrm{CO}_{2}$ and $\mathrm{CH}_{4}$ were sepa-

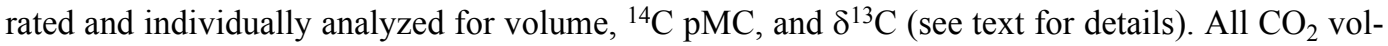
umes $\pm 0.1 \mathrm{~mL}$, and all ${ }^{14} \mathrm{C}$ results corrected for background (i.e. corrected for small amounts of ${ }^{14} \mathrm{C}$ introduced during sample processing).

\begin{tabular}{|c|c|c|c|c|c|c|c|c|c|}
\hline \multirow[b]{2}{*}{ Site } & \multirow[b]{2}{*}{$\begin{array}{l}\text { Depth } \\
\text { (m) }\end{array}$} & \multicolumn{4}{|c|}{ Recovered $\mathrm{CO}_{2}$ fraction } & \multicolumn{4}{|c|}{$\mathrm{CH}_{4}$ fraction (recovered as $\mathrm{CO}_{2}$ ) } \\
\hline & & $\begin{array}{l}\text { Volume } \\
(\mathrm{mL})\end{array}$ & $\begin{array}{l}\text { Publication } \\
\text { code } \\
\text { (SUERC-) }\end{array}$ & $\begin{array}{l}{ }^{14} \mathrm{C} \mathrm{pMC} \\
\pm 1 \sigma\end{array}$ & $\begin{array}{l}\delta^{13} C_{\mathrm{VPDB}} \\
\pm 0.1 \% \text { o }\end{array}$ & $\begin{array}{l}\text { Volume } \\
(\mathrm{mL})\end{array}$ & $\begin{array}{l}\text { Publication } \\
\text { code } \\
\text { (SUERC-) }\end{array}$ & $\begin{array}{l}{ }^{14} \mathrm{C} \mathrm{pMC} \\
\pm 1 \sigma\end{array}$ & $\begin{array}{l}\delta^{13} \mathrm{C}_{\mathrm{VPDB}} \\
\pm 0.1 \% \text { o }\end{array}$ \\
\hline A & 0.25 & 2.5 & 29812 & $98.16 \pm 0.45$ & -12.4 & 1.5 & 29802 & $97.30 \pm 0.43$ & $-68.0^{\mathrm{a}}$ \\
\hline A & 1.00 & 4.4 & 29811 & $86.66 \pm 0.42$ & -2.6 & 3.5 & 29801 & $82.14 \pm 0.38$ & -70.6 \\
\hline A & 2.00 & 2.0 & 29810 & $73.04 \pm 0.42$ & 3.4 & 3.6 & 29800 & $70.03 \pm 0.31$ & -65.3 \\
\hline A & 4.00 & 10.7 & 29807 & $60.63 \pm 0.48$ & 6.9 & 10.1 & 29797 & $60.53 \pm 0.28$ & -58.4 \\
\hline B & 0.25 & 8.6 & 29816 & $100.00 \pm 0.46$ & -8.0 & 3.3 & 29806 & $96.77 \pm 0.42$ & -64.2 \\
\hline B & 1.00 & 6.8 & 29815 & $83.44 \pm 0.40$ & -0.6 & 6.2 & 29805 & $77.30 \pm 0.34$ & -66.1 \\
\hline B & 2.00 & 4.2 & 29814 & $71.83 \pm 0.45$ & 7.6 & 19.9 & 29804 & $70.38 \pm 0.32$ & -64.0 \\
\hline B & 4.00 & 6.6 & 29813 & $61.74 \pm 0.47$ & 8.3 & 18.2 & 29803 & $61.36 \pm 0.28$ & -61.0 \\
\hline
\end{tabular}

aEstimated value due to insufficient sample volume.

siderably ${ }^{13} \mathrm{C}$-depleted relative to $\mathrm{CO}_{2}$. There was a less clear pattern in the $\delta^{13} \mathrm{C}$ values of $\mathrm{CH}_{4}$, but the most ${ }^{13} \mathrm{C}$-depleted values were found to occur at $1 \mathrm{~m}$ depth, and below this $\delta^{13} \mathrm{C}$ values for $\mathrm{CH}_{4}$ increased to $-58.4 \%$ and $-61.0 \%$ at a depth of $4 \mathrm{~m}$. 


\section{DISCUSSION}

\section{Validation of Laboratory Methods}

Previous studies have reported the separation of $\mathrm{CO}_{2}$ and $\mathrm{CH}_{4}$ from peatland gas samples for isotope analysis using cryogenic methods (e.g. Aravena et al. 1993; Charman et al. 1999; Clymo and Bryant 2008). However, since $\mathrm{CH}_{4}$ only partially condenses at liquid nitrogen temperatures $\left(-196^{\circ} \mathrm{C}\right)$, the separation from $\mathrm{CO}_{2}$ (which does completely condense at $-196{ }^{\circ} \mathrm{C}$ ) is not straightforward; Clymo and Bryant (2008) resolved this problem by performing the separation in stages. However, by exploiting the property of zeolite molecular sieve to strongly adsorb $\mathrm{CO}_{2}$, but not $\mathrm{CH}_{4}$ (due to its weak octopole moment), our new method provides a better separation of these gases in reduced processing time.

To test our separation procedure, we addressed the following questions. Firstly, does the molecular sieve trap $100 \%$ of the $\mathrm{CO}_{2}$ in the sample being analyzed? If not, then the $\mathrm{CO}_{2}$ component of a sample could suffer from isotopic fractionation effects and, in addition, the $\mathrm{CH}_{4}$ component would be contaminated by $\mathrm{CO}_{2}$ that was not trapped. Secondly, we questioned whether it was possible that even a small amount of sample $\mathrm{CH}_{4}$ could be trapped on the MSC and in doing so contaminate the $\mathrm{CO}_{2}$ component. The analysis of a mixture of standard gases $\left(\mathrm{CO}_{2}\right.$ and $\left.\mathrm{CH}_{4}\right)$ with known volumes and distinctly different isotopic composition would resolve these issues.

Earlier tests by Hardie et al. (2005) have shown that within certain limits, MSCs trap all of the $\mathrm{CO}_{2}$ from a standard gas mixture without undergoing significant fractionation or memory effects. The results from our tests almost overwhelmingly confirm the efficiency of the MSC to trap all of the $\mathrm{CO}_{2}$; yields of recovered samples were all $100 \%$, and with the exception of 1 sample, $\delta^{13} \mathrm{C}$ values of recovered $\mathrm{CO}_{2}$ were within measurement uncertainty of the original standard (Table 1). Of the 4 $\mathrm{CH}_{4}$ samples recovered from the standard gas mixtures, 3 had ${ }^{14} \mathrm{C}$ contents within measurement error of the $\mathrm{CH}_{4}$ blank, indicating that no ${ }^{14} \mathrm{C}$-enriched $\mathrm{CO}_{2}$ had made it beyond the $\mathrm{MSC}$ (and into the $\mathrm{CH}_{4}$-derived $\mathrm{CO}_{2}$ ).

It was notable, however, that from the standard gas with the greatest proportion of $\mathrm{CO}_{2}$ relative to $\mathrm{CH}_{4}$, the recovered $\mathrm{CH}_{4}$-derived $\mathrm{CO}_{2}$ had a ${ }^{14} \mathrm{C}$ concentration significantly higher than the $\mathrm{CH}_{4}$ blank and other samples. A small amount of atmospheric contamination at some stage of the sample processing could explain this result, or alternatively, it is possible that some $\mathrm{CO}_{2}$ from the standard gas mixture was not trapped by the MSC, resulting in contamination of the $\mathrm{CH}_{4}$-derived $\mathrm{CO}_{2}$ component.

There is a limit to how much $\mathrm{CO}_{2}$ a molecular sieve will adsorb and Garnett et al. (2009) have reported collection volumes of over $100 \mathrm{~mL}$ of $\mathrm{CO}_{2}$ on identical MSCs to those used in this study. However, trapping efficiency will decline as the sieve saturates, and therefore there will be a threshold above which some $\mathrm{CO}_{2}$ starts to bleed through (termed "breakthrough"). The MSCs that we used were developed to collect samples of $\sim 10 \mathrm{~mL} \mathrm{CO}_{2}$ with no breakthrough. However, in the present study, there is strong evidence to suggest that complete trapping of all $\mathrm{CO}_{2}$ occurred in samples up to and including a volume of $21.3 \mathrm{~mL}$ (Table 1), because the ${ }^{14} \mathrm{C}$ concentration of the $\mathrm{CH}_{4}$-derived $\mathrm{CO}_{2}$ was lower than the result obtained for the blank. Therefore, we can be confident that the molecular sieve method effectively removes the entire $\mathrm{CO}_{2}$ component of these gas mixtures so long as the $\mathrm{CO}_{2}$ component does not exceed $\sim 20 \mathrm{~mL}$ (in applications of the method it would be useful to determine the $\mathrm{CO}_{2}$ concentration of sample gases before processing to ensure this threshold would not be exceeded). 
For the single $\mathrm{CH}_{4}$ result with an elevated ${ }^{14} \mathrm{C}$ content of $0.64 \mathrm{pMC}$, by mass balance calculation, this value relative to the non-contaminated samples $(\sim 0.15 \mathrm{pMC})$ represents a contamination of the $\mathrm{CH}_{4}$-derived $\mathrm{CO}_{2}$ from the standard gas of $0.02 \mathrm{~mL}$, or $\sim 0.4 \%$ of the $4.9 \mathrm{~mL}$ recovered sample. This level of contamination would be too small to be detected by measurement of the yield volume (which was $100 \%$ ) and furthermore would shift the $\delta^{13} \mathrm{C}$ value of the sample by less than the $1 \sigma$ measurement precision (assuming the contaminant had a $\delta^{13} \mathrm{C}$ of $-27.0 \%$ ). Additionally, this extremely low level of contamination would insignificantly affect the ${ }^{14} \mathrm{C}$ results for field samples because of the similarity in age between the $\mathrm{CO}_{2}$ and $\mathrm{CH}_{4}$ fractions (it should also be noted that all field samples had a $\mathrm{CO}_{2}$ volume $<<20 \mathrm{~mL}$ ).

We also questioned whether the $\mathrm{CH}_{4}$ component of samples could contaminate the $\mathrm{CO}_{2}$ recovered by the molecular sieve. Theoretically, this is unlikely because Type $13 \mathrm{X}$ zeolite molecular sieve is known to have a much lower affinity for $\mathrm{CH}_{4}$ compared to $\mathrm{CO}_{2}$ (BDH, no date). Our results (Table 1) strongly suggest that the $\mathrm{CH}_{4}$ component of the mixed standard gases did not contaminate the recovered $\mathrm{CO}_{2}$ samples. Firstly, yields of recovered samples were all $100 \%$; if $\mathrm{CH}_{4}$ had contaminated the $\mathrm{CO}_{2}$ samples yields should have exceeded $100 \%$. Secondly, all ${ }^{14} \mathrm{C}$ results for the recovered $\mathrm{CO}_{2}$ fraction were within measurement uncertainty of the consensus value.

All $\delta^{13} \mathrm{C}$ values for recovered $\mathrm{CO}_{2}$ samples were within measurement uncertainty $(<2 \sigma)$ of the original standard gas with the exception of 1 sample, which had a slightly ${ }^{13} \mathrm{C}$-depleted value of $-27.5 \%$. For this 1 sample with a $\delta^{13} \mathrm{C}$ value not within analytical uncertainty of the standard value, mass balance was used to determine whether this shift in $\delta^{13} \mathrm{C}$ could have been caused by a component of $\mathrm{CH}_{4}{ }^{-}$ derived $\mathrm{CO}_{2}$ contamination. Assuming a $\delta^{13} \mathrm{C}$ for an uncontaminated $\mathrm{CO}_{2}$ sample of $-27.0 \%$, a shift of $0.5 \%$ would require $4 \%$ of the recovered $\mathrm{CO}_{2}$ to be derived from the $\mathrm{CH}_{4}$ component (with $\delta^{13} \mathrm{C}=$ $-39.7 \%$ ). However, a $4 \%$ contamination of the sample from $\mathrm{CH}_{4}$-derived $\mathrm{CO}_{2}$ would have shifted the ${ }^{14} \mathrm{C}$ content of the recovered $\mathrm{CO}_{2}$ sample by $\sim 4 \mathrm{pMC}$, which clearly was not the case (Table 1). This indicates that the single depleted $\delta^{13} \mathrm{C}$ result for the $\mathrm{CO}_{2}$ component cannot have occurred due to $\mathrm{CH}_{4}$-derived $\mathrm{CO}_{2}$ contamination. Thus, the results provide no suggestion of $\mathrm{CH}_{4}$ being trapped in the MSC and contaminating the $\mathrm{CO}_{2}$ component.

\section{Test of Sampling and Laboratory Methods on Field Samples}

Previous use of the sampling probes employed in this study proved their reliability for the collection of dissolved $\mathrm{CO}_{2}$ samples using a passive sampling method (Garnett and Hardie 2009). However, using the passive sampling approach, probes were not subjected to vacuum conditions like in the present study. There was therefore a concern that the probes might allow some water into the evacuated flasks, making necessary an additional step to extract dissolved gas from the water. However, no water was visible in any of the evacuated flasks, suggesting that they had remained leak-tight (the water table was always within $5 \mathrm{~cm}$ of the peat surface during the sampling period; thus, all samples were collected from below the water table). Furthermore, the probes had been in use at the site for one year, and showed no evidence of deterioration or water penetration. Therefore, the sampling probes performed well as a method to collect in situ samples of dissolved peat gases using evacuated flasks.

${ }^{14} \mathrm{C}$ results for samples collected at the same depth for both sites (Sites A and B) agreed very closely (Table 2, Figure 1). This was particularly evident with the 2 deepest sets $(2$ and $4 \mathrm{~m})$ where results for both $\mathrm{CO}_{2}$ and $\mathrm{CH}_{4}$ components were within measurement uncertainty $(<2 \sigma)$ of each other. ${ }^{14} \mathrm{C}$ results for these 2 depths also agreed very closely with dissolved $\mathrm{CO}_{2}$ results reported previously from Langlands Moss using the passive sampling method (Garnett and Hardie 2009). For example, in the present study the ${ }^{14} \mathrm{C}$ ages for the $\mathrm{CO}_{2}$ component collected from the 2 and $4 \mathrm{~m}$ depths at Site 
A were $2524 \pm 46$ and $4019 \pm 64 \mathrm{BP}$, both within $1 \sigma$ of the results for $\mathrm{CO}_{2}$ collected at the same depths, only $\sim 3 \mathrm{~m}$ away, using the passive sampling method ( $2571 \pm 48$ and $4006 \pm 63 \mathrm{BP}$, respectively; Garnett and Hardie 2009). Therefore, the similarities in ${ }^{14} \mathrm{C}$ results between Sites A and B in this study (both $\mathrm{CO}_{2}$ and $\mathrm{CH}_{4}$ fractions), and the excellent agreement of the ${ }^{14} \mathrm{C}$ results for $\mathrm{CO}_{2}$ between this study and the earlier study, provide strong support that the new sampling and processing methods have performed reliably.

That we found very good agreement for ${ }^{14} \mathrm{C}$ results between duplicate samples from the 2 lowest depths reported in this study, and those in an earlier study, and given that we used exactly the same sampling methods for the 2 shallower depths, we think it unlikely that the poorer agreement in results from the shallower depths indicates a particular problem with either the sampling method or sample analysis. Instead, we consider that this more likely reflects greater variability in these layers, as a result of natural spatial variation and the transition in conditions and processes operating between the surface and deeper peat layers (see below). However, it should be noted that the MSCs that we employed were initially developed to collect samples of $\sim 5-10 \mathrm{~mL} \mathrm{CO}_{2}$, although in the present study some of the samples were considerably smaller ( 2 of which were from the 0.25 and $1 \mathrm{~m}$ depths of Site A; Table 2).

Greater variability was observed in the $\delta^{13} \mathrm{C}$ values of duplicate samples from each site, for both the $\mathrm{CO}_{2}$ and $\mathrm{CH}_{4}$ components of the dissolved peat gases (Table 2). For example, in the extreme the $\delta^{13} \mathrm{C}_{\text {of }} \mathrm{CO}_{2}$ from Site A at $2 \mathrm{~m}$ was $+3.4 \%$, whereas at Site $\mathrm{B}$ the value was $+7.6 \%$. An even greater difference (4.5\%) was found at $1 \mathrm{~m}$ depth on comparison of the $\delta^{13} \mathrm{C}$ values for $\mathrm{CH}_{4}$. There was no agreement (i.e. within measurement uncertainty) in $\delta^{13} \mathrm{C}$ values between the 2 sites for either $\mathrm{CO}_{2}$ or $\mathrm{CH}_{4}$ at any of the 4 depths. Possible explanations for these observations are discussed below.

Firstly, the results may simply reflect the spatial (and possibly temporal) variability in $\delta^{13} \mathrm{C}$ of both $\mathrm{CO}_{2}$ and $\mathrm{CH}_{4}$ in these systems. For example, Waldron et al. (1999) reported $\delta^{13} \mathrm{C}$ values for $\mathrm{CH}_{4}$ at Ellergower Moss (near New Galloway, UK) substantially different (up to $\sim 10 \%$ ) to results later reported by Clymo and Bryant (2008) from similar depths in the same peatland, only $75 \mathrm{~m}$ away. Alternatively, given the extreme difference in $\delta^{13} \mathrm{C}$ values for both the $\mathrm{CO}_{2}$ and $\mathrm{CH}_{4}$ components of peat gases, it would only take a small amount of carbon from 1 fraction contaminating the other (during sample processing) to cause a shift in the measured $\delta^{13} \mathrm{C}$ value. However, we think it unlikely that any contamination between the $\mathrm{CO}_{2}$ and $\mathrm{CH}_{4}$ could have occurred because the tests of the laboratory methods demonstrated that this would only occur if the $\mathrm{CO}_{2}$ component of the gases was greater than $\sim 21 \mathrm{~mL}$. In fact, the maximum amount of $\mathrm{CO}_{2}$ in the field samples was much lower (maximum $=10.7 \mathrm{~mL}$ ).

The field-collected samples would likely contain components besides the $\mathrm{CO}_{2}, \mathrm{CH}_{4}$, and $\mathrm{N}_{2}$ that were present in the standard gases (e.g. water vapor). During processing, the molecular sieve would remove water vapor in preference to $\mathrm{CO}_{2}$ due to its greater affinity for water (BDH, no date). If present in sufficient quantities, water could reduce the ability of the molecular sieve to trap $\mathrm{CO}_{2}$, thus allowing some sample $\mathrm{CO}_{2}$ to pass through the molecular sieve trap and contaminate the $\mathrm{CH}_{4}$ derived $\mathrm{CO}_{2}$ samples. However, as previously mentioned, liquid water was not observed in the evacuated flask samples following field collection, and observed levels of moisture from desorbing of the molecular sieves were no higher than normal. Given that the volume of $\mathrm{CO}_{2}$ contained in the samples was too small to have saturated an MSC, we think it unlikely that incomplete trapping of the $\mathrm{CO}_{2}$ component in the field samples contributed to the more variable $\delta^{13} \mathrm{C}$ values.

Failure to achieve isotopic equilibration between the sample flasks and surrounding peat during sample collection could have caused variable and unrepresentative $\delta^{13} \mathrm{C}$ values in both the $\mathrm{CO}_{2}$ and 
$\mathrm{CH}_{4}$ components. It should be noted that the $\mathrm{CO}_{2}$ component of sample gases was ${ }^{13} \mathrm{C}$-depleted in all Site A samples, relative to the paired Site B samples collected from the same depth. Evacuated flasks for Site A samples were attached to sampling probes for 7 days, whereas Site B samples were collected over 12 days. We therefore suggest that the Site A samples could have been isotopically fractionated due to insufficient equilibration time in the field (isotopic fractionation would favor proportionally more of the lighter ${ }^{12} \mathrm{CO}_{2}$ entering the evacuated flasks first and would therefore be consistent with the ${ }^{13} \mathrm{C}$-depleted $\mathrm{CO}_{2}$ observed for Site A). While we cannot rule out that this process has affected the results, the $\delta^{13} \mathrm{C}$ values for the $\mathrm{CH}_{4}$ component do not completely support this because 1 of the 3 paired sets of samples showed greater ${ }^{13} \mathrm{C}$ depletion at Site B. Further investigation into possible isotopic fractionation during sampling, and guidance of the required sampling time to achieve equilibration is clearly required (using a not too dissimilar sampling method Waldron et al. [1999] determined that equilibration required 14 days). It should be noted that these isotopic fractionation issues only affect the $\delta^{13} \mathrm{C}$ results (which were in any case similar to results from other studies) since the ${ }^{14} \mathrm{C}$ results were corrected for mass-dependent fractionation by normalizing to a $\delta^{13} \mathrm{C}$ of $-25 \%$ (Stuiver and Polach 1977).

\section{Field Experiment - Comparison with Other Studies}

Previous studies of dissolved gases in peatlands have shown the $\mathrm{CO}_{2}$ component to be older (Charman et al. 1994), younger (Charman et al. 1999), or essentially the same age (Aravena et al. 1993; Chanton et al. 2008) as the $\mathrm{CH}_{4}$ component of dissolved gases. Our results are in agreement with the latter 2 studies in that the $\mathrm{CO}_{2}$ component was either slightly younger, or the same age as the $\mathrm{CH}_{4}$ component collected from the same depth. Our ${ }^{14} \mathrm{C}$ results are also in agreement with Clymo and Bryant (2008) who found that $\mathrm{CO}_{2}$ was younger than $\mathrm{CH}_{4}$ in the surface $0-4 \mathrm{~m}$ of the peatland they studied.

Increasingly ${ }^{13} \mathrm{C}$-enriched $\mathrm{CO}_{2}$ with depth has been reported by many studies, and our results agree well with the general pattern of published results (e.g. see Clymo and Bryant 2008). $\delta^{13} \mathrm{C}$ values of up to $\sim+6$ to $+10 \%$ for $\mathrm{CO}_{2}$, and highly ${ }^{13} \mathrm{C}$-depleted $\mathrm{CH}_{4}$ (about $-60 \%$ ) in peat gases have previously been attributed to methanogenesis. Several authors have used the calculation of $\alpha_{c}$ (Whiticar et al. 1986) to assess the contributions of acetate fermentation and $\mathrm{CO}_{2}$ reduction to $\mathrm{CH}_{4}$ production within peat bogs, where $\alpha_{\mathrm{c}}=\left(\delta^{13} \mathrm{C}_{\mathrm{CH} 4}+1000\right) /\left(\delta^{13} \mathrm{C}_{\mathrm{CO} 2}+1000\right)$. For Langlands Moss, we calculate $\alpha_{\mathrm{c}}$ to range from 0.929 to 0.943 , which agrees closely with values of $0.928-0.933$ from Clymo and Bryant (2008), 0.937 to 0.942 from Aravena et al. (1993), and 0.932 to 0.934 from Charman et al. (1999), and similarly indicates that $\mathrm{CH}_{4}$ production is mainly by $\mathrm{CO}_{2}$ reduction, as also reported by others (e.g. Lansdown et al. 1992). It was evident, however, that in the sample nearest the peatland surface $(0.25 \mathrm{~m})$ that $\alpha_{\mathrm{c}}$ was significantly higher than deeper samples (both in this study and results from Clymo and Bryant [2008]; Figure 2), which may be an indication of contributions to methanogenesis by acetate fermentation, previously observed for surface layers in peatlands by Hornibrook et al. (1997) and Steinmann et al. (2008).

Steinmann et al. (2008) state that $\mathrm{CO}_{2}$ from respiration in the aerobic surface layers (acrotelm) contributes $\mathrm{CO}_{2}$ to the deeper layers of a peatland (catotelm), influencing the $\delta^{13} \mathrm{C}$ profile by slowing the trend of increasing ${ }^{13} \mathrm{C}$ enrichment of $\mathrm{CO}_{2}$ with depth (assuming acrotelm-derived $\mathrm{CO}_{2}$ with $\delta^{13} \mathrm{C}$ about $-27 \%$ ). With depth, the volume of this respired $\mathrm{CO}_{2}$ decreases as it is progressively exhausted during reduction to $\mathrm{CH}_{4}$. Our ${ }^{14} \mathrm{C}$ results may provide direct evidence of acrotelm-derived $\mathrm{CO}_{2}$ within the samples collected from the top $1 \mathrm{~m}$. Unlike other depths in the profile, at $1 \mathrm{~m}$ the $\mathrm{CO}_{2}$ was significantly younger in ${ }^{14} \mathrm{C}$ age compared to the $\mathrm{CH}_{4}$ component, suggesting contributions of younger carbon, which must derive from higher in the profile. This extra carbon cannot have been 


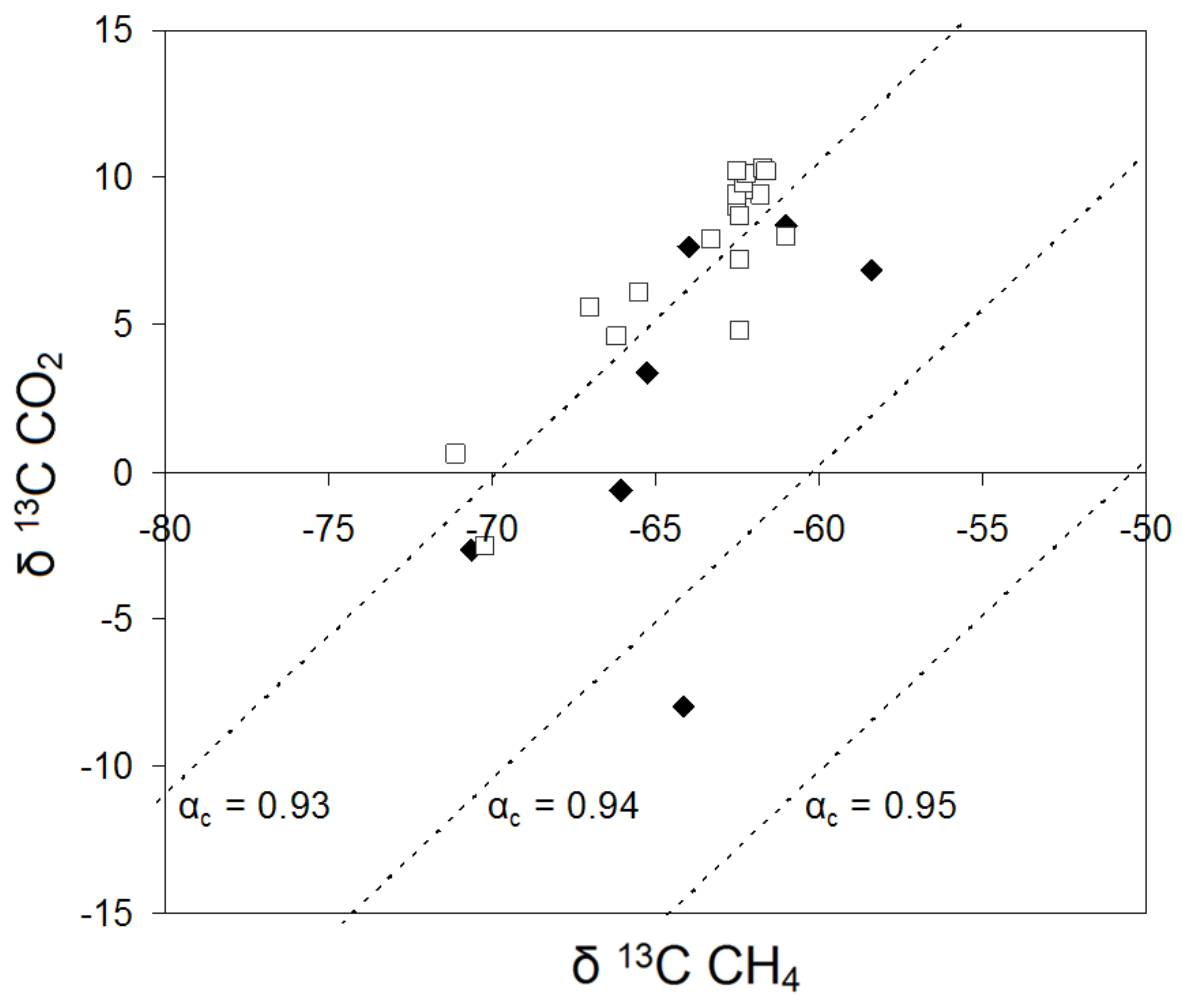

Figure 2 Plot of $\delta^{13} \mathrm{C}_{\mathrm{VPDB}}(\%)$ of $\mathrm{CO}_{2}$ versus $\delta^{13} \mathrm{C}_{\mathrm{VPDB}}(\%)$ of $\mathrm{CH}_{4}$ in dissolved gas samples collected from Langlands Moss, East Kilbride, UK (filled diamonds) and Ellergower Moss, near New Galloway, UK (open squares). Dashed lines represent different values of $\alpha_{c}$; values $<0.95$ suggest methanogenesis via $\mathrm{CO}_{2}$ reduction, values $>0.95$ imply acetate fermentation as the carbon pathway (see text; Whiticar et al. 1986). Note the outlier falling between $\alpha_{c} 0.94$ and 0.95 , which represents the sample from nearest the peatland surface $(0.25 \mathrm{~m}$ depth). Ellergower Moss values from Clymo and Bryant (2008).

derived from dissolved organic carbon (DOC), which has been identified as one of the forms of carbon that may be transported in the peat profile (e.g. Aravena et al. 1993), and is clearly a source for gases in peatlands (Chanton et al. 2008), because although this process would lead to peat gases younger in age than the surrounding peat, it would not lead to $\mathrm{CO}_{2}$ being younger than $\mathrm{CH}_{4}$ at the same depth.

Reduction of acrotelm-derived $\mathrm{CO}_{2}$ that has diffused into the deeper layers of the peat profile would result in the production of $\mathrm{CH}_{4}$ that is considerably ${ }^{14} \mathrm{C}$-enriched relative to $\mathrm{CH}_{4}$ produced in situ. If as suggested by Steinman et al. (2008) there is progressive conversion of the acrotelm-derived $\mathrm{CO}_{2}$ to $\mathrm{CH}_{4}$ with depth, then a point may be reached when more of the acrotelm-derived gas exists as $\mathrm{CH}_{4}$ rather than $\mathrm{CO}_{2}$. This could explain why Clymo and Bryant (2008) found $\mathrm{CO}_{2}$ to be younger than $\mathrm{CH}_{4}$ in the upper layers of the catotelm, but $\mathrm{CH}_{4}$ to be younger than $\mathrm{CO}_{2}$ below about $4 \mathrm{~m}$. This could also explain the convergence in ${ }^{14} \mathrm{C}$ ages between $\mathrm{CO}_{2}$ and $\mathrm{CH}_{4}$ with depth in our results from Langlands Moss; however, because we did not sample below $4 \mathrm{~m}$, we may not have reached the depths where the majority of acrotelm-derived $\mathrm{CO}_{2}$ had been converted to $\mathrm{CH}_{4}$. Nevertheless, this explanation concurs with the assertion of Clymo and Bryant (2008) that diffusion is far more important than mass flow in explaining the age profile of gases in these peatlands, and highlights the value in ${ }^{14} \mathrm{C}$ analysis of both $\mathrm{CO}_{2}$ and $\mathrm{CH}_{4}$. 


\section{CONCLUSIONS}

New methods for the in situ collection of dissolved gases from peat profiles, and subsequent isolation of the $\mathrm{CO}_{2}$ and $\mathrm{CH}_{4}$ components have been developed and tested. The field sampling equipment is simple to construct and install, and causes minimal site disturbance. The molecular-sieve-based procedures to separate $\mathrm{CO}_{2}$ and $\mathrm{CH}_{4}$ components of sample gases in the laboratory are more rapid than existing techniques, yet perform the task extremely well as shown by tests on standard gas mixtures of known isotopic composition. Results from field samples collected across a range of depths from a raised peat bog showed carbon isotope values for $\mathrm{CO}_{2}$ and $\mathrm{CH}_{4}$ with similar trends and magnitude to previous studies. These results confirm earlier suggestions of the importance of $\mathrm{CO}_{2}$ reduction for methanogenesis in the deeper layers of some peat bogs, and the ${ }^{14} \mathrm{C}$ results in particular show the influence of acrotelm-derived $\mathrm{CO}_{2}$ in the catotelm.

\section{ACKNOWLEDGMENTS}

We thank staff at the NERC Radiocarbon Facility (Environment) and SUERC AMS Facility. NERC is acknowledged for funding the isotope analyses and we are grateful to John Hawell and South Lanarkshire Council for site access, and to an anonymous reviewer whose comments led to improvements in the manuscript.

\section{REFERENCES}

Aravena R, Warner BG, Charman DJ, Belyea LR, Mathur SP, Dinel H. 1993. Carbon isotopic composition of deep carbon gases in an ombrogenous peatland, northwestern Ontario, Canada. Radiocarbon 35(2):271-6.

BDH. No date. 'Union Carbide' molecular sieves for selective adsorption. BDH Chemicals Ltd, UK.

Chanton J, Glaser PH, Chasar LS, Burdige DJ, Hines ME, Siegel DI, Tremblay LB, Cooper WT. 2008. Radiocarbon evidence for the importance of surface vegetation on fermentation and methanogenesis in contrasting types of boreal peatlands. Global Biogeochemical Cycles 22: GB4022, doi:10.1029/ 2008 GB003274.

Chapman SJ, Thurlow M. 1996. The influence of climate on $\mathrm{CO}_{2}$ and $\mathrm{CH}_{4}$ emissions from organic soils. Agricultural and Forest Meteorology 79(4):205-17.

Charman DJ, Aravena R, Warner BG. 1994. Carbon dynamics in a forested peatland in north-eastern Ontario, Canada. Journal of Ecology 82(1):55-62.

Charman DJ, Aravena R, Bryant CL, Harkness DD. 1999. Carbon isotopes in peat, $\mathrm{DOC}, \mathrm{CO}_{2}$, and $\mathrm{CH}_{4}$ in a Holocene peatland on Dartmoor, southwest England. Geology 27(6):539-42.

Chasar L, Chanton J, Glaser PH, Siegel DI, Rivers J. 2000. Radiocarbon and stable carbon isotopic evidence for transport and transformation of dissolved organic carbon, dissolved inorganic carbon, and $\mathrm{CH}_{4}$ in a northern Minnesota peatland. Global Biogeochemical Cycles 14(4):1095-108.

Clymo RS, Bryant CL. 2008. Diffusion and mass flow of dissolved carbon dioxide, methane, and dissolved organic carbon in a 7-m deep raised peat bog. Geochimica et Cosmochimica Acta 72(8):2048-66.
Coleman D, Liu C-L, Riley KM. 1988. Microbial methane in the shallow Paleozoic sediments and glacial deposits of Illinois, USA. Chemical Geology 71(1-3): 23-40.

Freeman S, Bishop P, Bryant C, Cook G, Dougans D, Ertunc T, Fallick A, Ganeshram R, Maden C, Naysmith P, Schnabel C, Scott M, Summerfield M, Xu S. 2007. The SUERC AMS laboratory after 3 years. Nuclear Instruments and Methods in Physics Research B 259(1):66-70.

Garnett MH, Hardie SML. 2009. Isotope $\left({ }^{14} \mathrm{C}\right.$ and $\left.{ }^{13} \mathrm{C}\right)$ analysis of deep peat $\mathrm{CO}_{2}$ using a passive sampling technique. Soil Biology and Biochemistry 41(12): 2477-83.

Garnett MH, Hartley IP. 2010. A passive sampling method for radiocarbon analysis of atmospheric $\mathrm{CO}_{2}$ using molecular sieve. Atmospheric Environment 44(7):877-83.

Garnett MH, Hartley IP, Hopkins DW, Sommerkorn M, Wookey PA. 2009. A passive sampling method for radiocarbon analysis of soil respiration using molecular sieve. Soil Biology and Biochemistry 41(7):1450-6.

Gulliksen S, Scott M. 1995. Report of the TIRI workshop, Saturday 13 August, 1994. Radiocarbon 37(2): 820-1.

Gut A, Blatter A, Fahrni M, Lehmann BE, Neftel A, Staffelbach T. 1998. A new membrane tube technique (METT) for continuous gas measurements in soils. Plant and Soil 198(1):79-88.

Hardie SML, Garnett MH, Fallick AE, Rowland AP, Ostle NJ. 2005. Carbon dioxide capture using a zeolite molecular sieve sampling system for isotopic studies $\left({ }^{13} \mathrm{C}\right.$ and ${ }^{14} \mathrm{C}$ ) of respiration. Radiocarbon 47(3):441-51. 
Hornibrook ERC, Longstaffe FJ, Fyfe WS. 1997. Spatial distribution of microbial methane production pathways in temperate zone wetland soils: stable carbon and hydrogen isotope evidence. Geochimica et Cosmochimica Acta 61(4):745-53.

Lansdown JM, Quay PD, King SL. 1992. $\mathrm{CH}_{4}$ production via $\mathrm{CO}_{2}$ reduction in a temperate bog: a source of ${ }^{13} \mathrm{C}$-depleted $\mathrm{CH}_{4}$. Geochimica et Cosmochimica Acta 56(9):3493-503.

Nykänen H, Heikkinen JEP, Pirinen L, Tiilikainen K, Martikainen PJ. 2003. Annual $\mathrm{CO}_{2}$ exchange and $\mathrm{CH}_{4}$ fluxes on a subarctic palsa mire during climatically different years. Global Biogeochemical Cycles 17: 1018, doi:10.1029/2002GB001861.

Slota Jr PJ, Jull AJT, Linick TW, Toolin LJ. 1987. Preparation of small samples for ${ }^{14} \mathrm{C}$ accelerator targets by catalytic reduction of CO. Radiocarbon 29(2): 303-6.

Steinmann P, Eilrich B, Leuenberger M, Burns SJ. 2008. Stable carbon isotope composition and concentrations of $\mathrm{CO}_{2}$ and $\mathrm{CH}_{4}$ in the deep catotelm of a peat bog. Geochimica et Cosmochimica Acta 72(24):6015-26.

Stuiver M, Polach HA. 1977. Discussion: reporting of ${ }^{14} \mathrm{C}$ data. Radiocarbon 19(3):355-63.

Waldron S, Hall AJ, Fallick AE. 1999. Enigmatic stable isotope dynamics of deep peat methane. Global Biogeochemical Cycles 13(1):93-100.

Whiticar MJ, Faber E, Schoell M. 1986. Biogenic methane formation in marine and freshwater environments: $\mathrm{CO}_{2}$ reduction $v s$. acetate fermentation - isotope evidence. Geochimica et Cosmochimica Acta 50(5):693709. 